\title{
Failure of Flower Bud Formation in Brassica Plants Associated with Phytoplasma Infection
}

\author{
Maria Kamińska (Correponding author) \& Hanna Berniak \\ Department of Plant Protection, Institute of Horticulture \\ 96-100 Skierniewice, Konstytucji 3 Maja 1/3, Poland \\ E-mail: maria.kaminska@insad.pl
}

Piotr Kamiński

Department of Genetics, Breeding and Biotechnology

Institute of Horticulture, 96-100 Skierniewice, Konstytucji 3 Maja 1/3, Poland

Received: June 9, 2011

Accepted: July 1, $2011 \quad$ Online Published: December 21, 2011

doi:10.5539/jas.v4n2p219

URL: http://dx.doi.org/10.5539/jas.v4n2p219

\begin{abstract}
Detection of phytoplasma classified in phylogenetic group 16SrI, 'Ca. Phytoplasma asteris', in the plants of interspecific genotypes of Brassica oleracea $x$ Brassica napus and their back-cross toward B. oleracea (IW7.7xB1) is reported in Poland. The presence of phytoplasmas in leaves of plants showing failure of flower bud formation but not in the asymptomatic hybrids was demonstrated by polymerase chain reaction assay employing phytoplasma universal P1/P7 primer pair. Amplified cDNA fragments of two phytoplasma isolates were sequenced. The nucleotide sequences of the Brassica hybrids phytoplasma isolates showed more than $98,5 \%$ similarity with the corresponding fragments of sequence of phytoplasmas belonging to group $16 \mathrm{SrI}$, ' $\mathrm{Ca}$. Phytoplasma asteris'.
\end{abstract}

Keywords: Brassica, Flower Bud Failure, Phytoplasma, PCR, Sequencing

\section{Introduction}

Phytoplasmas are non-helical, mycoplasma-like bacteria which lack cell walls. These specialized bacteria are insect-transmitted and can cause devastating diseases in crops and natural ecosystems worldwide (Seemüller et al., 1998; Lee et al., 2000; Bertaccini, 2007; Hogenhout et al., 2008). In infected plants, phytoplasmas almost exclusively inhabit the phloem sieve tube elements. They are transmitted from plant to plant by phloem-feeding homopteran insects, mainly leafhoppers, and less frequently psyllids (Weintraub \& Beanland, 2006). Phytoplasmas may be involved in disrupted hormonal balance, impaired amino acid and carbohydrate translocation, inhibited photosynthesis and rapid senescence (Chang, 1998; Lepka et al., 1999; Bertamini et al., 2002; Cukrovic-Perica et al., 2007). Plants infected by phytoplasmas exhibit a wide range of symptoms. Specific symptoms include flower virescence and distortion, and other flower abnormalities resulting in plant sterility, leaf discoloration and malformation, abnormal shoot branching and stunted growth. Symptoms of diseased plants may vary depending on the phytoplasma isolate, the host plant, stage of the disease, age of plant, time of infection and environmental conditions (Seemüller et al., 1998; Lee et al., 2000). Sporadically, phytoplasma infected plants are non-symptomatic over their life; a temporary or permanent remission of symptoms may also occur.

In the last two decades the economic importance of some plant diseases associated with phytoplasma infection has increased considerably in many countries. Using molecular-based techniques for detection and identification, several phytoplasmas were found to be associated with diseases of about a thousand plant species (Lee et al., 2000; Bertaccini, 2007).

In Brassicacea family, retarded growth, shoot proliferation and flower virescence associated with phytoplasma infection, have been reported from Europe, Nord America and Iran. In Europe phytoplasma infection have been observed in diseased cabbage (Brassica oleracea var. capitata) (Bertaccini et al., 1990, Marcone et al., 1997), 
sprouting broccoli (Brassica oleracea var. Italica) (Marcone \& Ragozzino, 1995; Marcone et al., 1997; Marzachi et al., 1999), turnip (Brassica rapa var. rapifera), kale (Brassica oleracea var. Palmifolia), wild radish (Raphanus raphanistrum) (Marcone \& Ragozzino, 1995; Marcone et al., 1997), Brussels sprout (Brassica oleraceae L. var. gemmifera DC) (Marzachi et al., 1999) and oilseed rape (Brassica napus) (Horvath, 1969; Vibio et al., 1996, Bertaccini et al., 1998; Starzycki \& Starzycka, 2000; Maliogka et al., 2009). Since the 1980s, in Alberta, Canada, symptoms of canola yellows similar to those of green petal of oilseed rape, have been observed in canola plants (Brassica napus and Brassica rapa) (Wang \& Hiruki, 2001; Olivier et al., 2006). In 2000 , in southwestern Texas, about $5 \%$ of cabbage plants displayed symptoms of purple leaf discoloration and sprouts proliferation characteristic of phytoplasma (Lee et al., 2001; 2003). Very recently, in Iran, cabbage disease yellows damaged cabbage up to $50 \%$ in certain fields (Salehi at al., 2007).

On the basis of molecular analyses, phytoplasmas associated with shoot proliferation, flower virescence and malformation of plants belonging to the Brassicacea family in Europe and USA were identified as members of 'Ca. Phytoplasma asteris', subgroup 16SrI-B (Bertaccini et al., 1998; Marzachi et al., 1999; Lee et al., 2001, 2003; Maliogka et al., 2009). Most phytoplasmas associated with yellows-type symptoms of canola plants in Canada belong to subgroup 16SrI-A or 16SrI-B (Wang \& Hiruki, 2001; Olivier et al., 2006), while phytoplasma associated with Iranian cabbage disease is related to ' $\mathrm{Ca}$. Phytoplasma trifolii', subgroup 16SrVI-A (Salehi at al., 2007). Very recently, Kamiński et al. (2010) reported the new disease of stunting, severe leaf malformation and failure of flower buds in Brussels sprout plants in Poland, associated with aster yellows phytoplasma infection.

This past season, we experienced a minor problem with some interspecific crosses of Brassica spp. plants grown in the greenhouse for scientific purposes. The exposure for several weeks at temperature between $0-9^{\circ} \mathrm{C}$ is commonly required by biennial plants of Brassica spp. for their vernalization to initiate generative stage and bud formation (Dixon, 2007). However, some of the plants exhibited production of green foliage and complete flower bud failure after vernalization period, while other genotypes created normally developed flower stacks (Fig.1).

The objective of the present study was to detect and identify the presumed causal agents associated with the disease symptoms observed in Brassica plants in Poland and to determine if they were related to phytoplasmas detected in several Brassicaceae crops with other symptoms.

\section{Materials and Methods}

\subsection{Symptom observation and plant material}

The observations were carried out on the interspecific genotypes of B. oleracea $x$ B. napus (B1) and their back-cross progeny toward B. oleracea (IW7.7xB1) growing in the greenhouse of the former Research Institute of Vegetable Crops, now Institute of Horticulture, Skierniewice, Poland.

The interspecific crosses of B. oleracea $\times$ B. napus (B1) were self-pollinated at the beginning of April 2009 and back-crossed toward B. oleracea genotypes. The obtained seeds were sown at the beginning of September 2009 in the greenhouse. Seedlings at 14-16 true leaf stage were vernalized from the beginning of December 2009 until the end of February 2010 in the temperature $4-8^{\circ} \mathrm{C}$ under natural day-length. In March 2010 the vernalized genotypes were placed in 51 plastic pots and in sterile medium and grown in an insect-proof greenhouse at $15 \pm 28^{\circ} \mathrm{C}$.

For PCR amplification samples of leaves from five Brassica plants (four Brassica oleracea $\mathrm{x}$ B. napus and one IW7.7 x B1) showing failure of flower buds and three healthy looking B. oleracea $\times$ B. napus plants were collected in April and July 2010. Samples of leaves of Catharanthus roseus inoculated by grafting with the reference strain of aster yellows phytoplasma (AY1, 16SrI-B, kindly supplied by Dr. I.-M. Lee, Beltsville, USA) were also included in this study.

\subsection{DNA extraction and PCR amplification}

Total DNA was extracted from frozen leaf midribs using DNeasy Plant Mini Kit (Qiagen, Biokom, Poland) according to manufacturer's recommendation.

Extracted nucleic acids were used as templates for direct PCR with universal primers P1/P7 (Deng \& Hiruki, 1991; Schneider et al., 1995). Products from the first round of PCR were diluted 25 times and then used in nested reactions as templates for amplification with universal primers R16F2n/R16R2 (Gundersen \& Lee, 1996; Lee et. al., 1993). All the PCR assays were run under parameters described previously by Śliwa et. al. (2008).

The amplification products $(5 \mu \mathrm{l})$ were analyzed by $1 \%$ agarose gel electrophoresis in $0.5 \mathrm{x}$ TBE $(45 \mathrm{mM}$ Tris-borate, $1 \mathrm{mM}$ EDTA, $\mathrm{pH} 8.3)$ buffer followed by staining with ethidium bromide $\left(0.5 \mu \mathrm{g} \cdot \mathrm{ml}^{-1}\right)$ and 
visualized with UV transilluminator (Syngen Biotech, Poland).

\subsection{Sequencing and computer analysis}

Nested PCR-amplified products obtained for samples from Brassica oleracea x B. napus and IW7.7 x B1 pants were resolved by electrophoresis, cut from the gel and purified using QIAquick PCR Purification Kit (Qiagen, Biokom, Poland). Purified rDNAs were directly sequenced in Maria Skłodowska Memorial Cancer Center and Institute of Oncology, Warsaw, Poland, using AbiPrism 3100 Genetic Analyzer apparatus (Applied Biosystems, USA). Sequencing was performed with primers R16F2n/R16R2.

Obtained sequences were analyzed using Lasergene v. 7.1 software package (DNASTAR, USA). Consensus sequences were produced using SeqMan program, while determination of similarity level of analyzed 16S rRNA gene fragments was done with MegAlign program. Comparison of obtained sequences with sequences available in GenBank was accomplished using BLAST service available at http://www.ncbi.nlm.nih.gov:80/BLAST. Phylogenetic relationship was estimated by application of the neighbor-joining method and subsequent bootstrap analysis in the MEGA software v. 4.0.2 (Tamura et al., 2007). Sequences of tested phytoplasmas were compared with analogous 16S rRNA gene sequence fragments of phytoplasmas found in Brussles sprout plants in Poland (acc. No. GQ240826, GQ240827, HM480047) as well as selected phytoplasma strains, being members of: ' $\mathrm{Ca}$. Phytoplasma asteris' (M86340, L33767, U89378, M30790), 'Ca. Phytoplasma solani' (AF248959), 'Ca. Phytoplasma pyri' (Y16392), 'Ca. Phytoplasma mali' (AF248958), 'Ca. Phytoplasma pruni' (L33733), 'Ca. Phytoplasma palmae' (AF434989), 'Ca. Phytoplasma cynodontis' (AF248961), 'Ca. Phytoplasma phoenicium' (AF248957), 'Ca. Phytoplasma pini' (AJ632156), 'Ca. Phytoplasma luffae' (AF248956), 'Ca. Phytoplasma ulmi' (Y16387), 'Ca. Phytoplasma trifolii' (AY270156) and 'Ca. Phytoplasma fraxini' (AF105317).

\section{Results}

\subsection{Symptoms}

The affected glasshouse-grown Brassica genotypes in the second year of their growth developed green foliage but failure of flower buds (Fig. 1). The occurrence of this symptom was noted in four out of 12 B. oleracea $x B$. napus and in one out of four IW7.7 x B1 plants. The other healthy looking plants of those crosses stored and grown in the same conditions were free of this type of symptoms; they developed flowers and produced seeds.

\subsection{Phytoplasma detection and identification}

Specific products were obtained in direct and nested PCR with the universal primer pairs for DNA samples isolated in April from all five Brassica (four B. oleracea X B. napus and one IW7.7 x B1) plants showing failure of flower buds and from the control samples of the reference strain AY1. No visible product was amplified by the direct nor nested PCR for DNA samples collected from the same plants at the end of July nor for DNA samples of three healthy looking Brassica hybrids.

PCR products obtained using R16F2n/R16R2 primer pair for samples of B. oleracea $\times$ B. napus and IW7.7 x_B1 plants were sequenced. Nucleotide sequence analysis of the PCR-amplified 16S rRNA gene fragment of the phytoplasmas isolated revealed that they were closely related to phytoplasma members of 16SrI group (Figure 2). Sequences of two phytoplasmas found in symptomatic Brassica were identical (GenBank accession numbers HM480044 and HM480045), and they showed more than $98 \%$ identity to the sequences of 'Candidatus Phytoplasma asteris'.

\section{Discussion}

Several phytoplasma diseases can cause various types of symptoms and damage to a variety of economically important crops including vegetables, ornamentals, pomological and agricultural plants (Marcone et al., 1997; Bertaccini et al., 1998; Seemüller et al., 1998; Lee et al., 2004).

The present study provides evidence for the presence of phytoplasma in Brassica plants with growth abnormalities, but not in the healthy ones, and suggests that the flower bud failure could be due to phytoplasma infection. The observed abnormalities in the development of phytoplasma-infected plants suggest hormone imbalance (Chang, 1998; Musetti, 2010). However, it is not known whether phytoplasmas synthesize plant growth regulators, or if phytoplasmas change the natural levels of endogenous plant hormones (Lee et al., 2000). $\mathrm{Up}$ to our knowledge, failure of flower bud formation and consequently failure of seed production were occasionally observed in Brassica plants and they were assumed to be associated with not sufficient vernalization. Many plant species require the exposure to several weeks of cool temperatures to initiate bud formation or new growth and stimulate flowering (Elers \& Wiebe, 1984; Dennis \& Peacock, 2009). The analyses of Giakountis \& Coupland (2008) strongly argue that the FLOWERING LOCUS T (FT protein) is transported 
from the companion cells to the meristem through the phloem sieve elements, and that this transport is required for floral induction. It is also suggested that the biosynthetic pathway of the growth hormone GA is activated in the apex of vernalized plants (Winfield et al., 2009). Since phytoplasmas live and multiply in functional phloem sieve tube elements the main effect of phytoplasma infection is the impairment of the sieve tube function. We assume that phytoplasmas can make difficulty in transport of FT protein from the companion cells to the meristem through the phloem sieve elements, and consequently they inhibit flower bud development. However, the exact mechanisms involved in symptoms development or the genes that control these events are still poorly understood (Musetti, 2010).

The disease symptoms observed in phytoplasma affected Brassica plants in Poland are different from shoot proliferation and flower virescence reported in plants belonging to Brassicaceae family which were cultivated in other European countries (Bertaccini et al., 1990; 1998; Marcone \& Ragozzino, 1995; Marcone et al., 1997; Vibio et al., 1996; Marzachi et al., 1999; Maliogka et al., 2009) or leaf yellowing, phyllody and seed malformation observed in canola plants in Canada (Olivier et al., 2006), all associated with aster yellows phytoplasma infection. The observed failure of flower bud formation is similar to the symptoms previously observed in Tagetes patula and some lily cultivars phytoplasma affected (Kamińska \& Dziekanowska, 2001) as well as Brussels sprout plants (Kamiński et al., 2010). However, the affected Brassica hybrids did not show stem and leaf malformation observed in the diseased marigold, lily or Brussels sprout plants.

The disease of Brassica plants which was found in Poland for the first time showed total deficiency of flower buds. Great differences in the symptom expression of this and other aster yellows-type known diseases of Brassicas might suggest that they were caused by distant pathogens. However, the data obtained by PCR amplification and sequence analysis provide the evidence that the Polish disease of Brassica hybrids as well as diseases reported previously in the other Brassicacea crops were associated with aster yellows phytoplasma infection (Bertaccini et al., 1998; Marzachi et al., 1999; Maliogka et al., 2009). Phytoplasmas detected in affected Brassica hybrids were nearly identical with the sequences of other ' $C a$. Phytoplasma asteris' strains. Based on the results of this study and other reports from Europe and Canada, AY phytoplasma, mainly subgroup $16 \mathrm{Sr}-\mathrm{B}$, seems to be the most common yellows-type disease associated with various plant species. This ranking is consistent with the top position of the AY group among other phytoplasma groups worldwide (Seemüller et al., 1998; Marcone et al., 2000; Lee et al., 2004).

From the data available is known that classification based on RFLP and sequence analyses of the 16S rRNA gene alone does not reflect the full range of phenotypic properties. This gene does not always seem sufficiently variable to allow distinction of phytoplasmas that differ in plant host or vector specificity. Different phytoplasmas can cause very similar symptoms in certain plants; including phytoplasmas associated with big bud of tomato or grapevine yellows (Shaw et al., 1993; Daire et al., 1997). On the other hand, some closely related phytoplasmas can cause distinctly different symptoms in host plants. For example, 20 strains of European stone fruit yellows (ESFY) phytoplasmas were identical and indistinguishable based on primer specificity and RFLP profiles of ribosomal DNA (Kison \& Seemüller, 2001). However, they varied greatly in vector specificity and aggressiveness, ranging from nearly avirulent to highly virulent. Moreover, the diversity of the symptoms than can be caused by the same pathogen indicated that the phytoplasma-plant interaction involves physiological steps which are in very upstream position in the plant differentiation process. Recently, supplementary molecular markers have been identified for finer differentiation of closely related strains that cannot be distinguished by 16S rRNA gene sequence alone. Multi-locus sequence analyses will certainly provide additional information to the 16S rRNA gene-based phylogenetic backbone and enhance closely related strains (Zhao et al., 2010; Hodgettes \& Dickinson, 2010).

The present study provides evidence that the titre of phytoplasmas in Brassica plants with deficiency of flower buds was high and the pathogen could be detected in affected plants by direct PCR using universal phytoplasma primers. These results are in disagreement with our previous findings concerning phytoplasma infection in Brussels sprout (Kamiński et al., 2010) as well as with the results of Wang \& Hiruki (2001) and Olivier et al., (2006), who were not able to detect the aster yellows phytoplasma in tested canola plants by direct PCR in Canada. On the contrary to those results, in Italy and Greece (Bertaccini et al., 1998; Marzachi et al., 1999; Maliogka et al., 2009), the USA (Lee at al., 2003) and Iran (Salehi et al., 2007) the titre of phytoplasmas in Brassica spp. plants was high and they were detectable by direct PCR.

We suppose that the incidence of aster yellows phytoplasma in some Brassica plants in Poland may be correlated with mass occurrence of phytoplasma and vector sources in the last few years in many crops and weeds (Soika \& Kamińska, 2001; Kamińska \& Soika 2002; Kamińska, 2006) as well as with high plant susceptibility to 
phytoplasma. Because of the relatively short time of the study we could not state which factors, in addition to phytoplasma, were related with symptom expression of tested plants.

In order to evaluate the relationship between the occurrence of symptoms and the phytoplasma infection in Brassica plants extensive study should be done.

\section{References}

Bertaccini A. (2007). Phytoplasmas: diversity, taxonomy, and epidemiology. Frontiers in Bioscience, 12, 673-689. http://dx.doi.org/10.2741/2092

Bertaccini A., Davis R.E. \& Lee I.M. (1990). Distinction among mycoplasmalike organisms (MLOs) in Gladiolus, Ranunculus, Brassica and Hydrangea through detection with nonradioactive cloned DNA probes. Phytopathologia Mediterranea, 29, 107-113.

Bertaccini A., Vorackova Z., Vibio M., Franova J., Navratil M., Spak J. \& Nebesarova, J. (1998). Comparison of phytoplasmas infecting winter oilseed rape in the Czech Republic with Italian Brassica phytoplasmas and their relationship to the aster yellows group. Plant Pathology, 47, 317-324. http://dx.doi.org/10.1046/j.1365-3059.1998.00229.x

Bertamini M., Grando M.S., Muthuchelian K. \& Nedunchezhian N. (2002). Effect of phytoplasmal infection on photosystem II efficiency and thylakoid membrane protein changes in field grown apple (Malus pumila) leaves. Physiological and Molecular Plant Pathology, 61, 349-356. http://dx.doi.org/10.1006/pmpp.2003.0450

Chang C.J. (1998). Pathogenicity of aster yellows phytoplasma and Spiroplasma citri on periwinkle. Phytopathology, 88, 1347-1350. http://dx.doi.org/10.1094/PHYTO.1998.88.12.1347

Curković-Perica M., Lepedus H. \& Seruga-Musić M. (2007). Effect of indole-3-butyric acid on phytoplasmas in infected Cathananthus roseus shoots grown in vitro. FEMS Microbiology Letters, 268, 171-177. http://dx.doi.org/10.1111/j.1574-6968.2006.00577.x

Daire X., Clair D., Reinert W. \& Boudon-Padieu E. (1997). Detection and differentiation of grapevine yellows phytoplasmas belonging to the elm yellows group and the stolbur subgroup by PCR amplification of nonribosomal DNA. European Journal of Plant Pathology, 103, 507-514. http://dx.doi.org/10.1023/A:1008641411025

Deng S. \& Hiruki C. (1991). Amplification of 16S rRNA genes from culturable and nonculturable mollicutes. Journal of Microbiological Methods, 14, 53-61. http://dx.doi.org/10.1016/0167-7012(91)90007-D

Dennis E.S. \& Peacock W.J. (2009). Vernalization in cereals. Journal of Biology, 8, 57. http://dx.doi.org/10.1186/jbiol156

Dixon G. R. (2007). Vegetable Brassicas and Related Crucifers. Crop Production Science in Horticulture, 14, CAB International (Eds).

Elers B. \& Wiebe H.J. (1984). Flower formation of Chinese cabbage. II. Anti-vernalization and short-day treatment. Scientia Horticulturae, 22, 219-231. http://dx.doi.org/10.1016/0304-4238(84)90055-4

Giakountis A. \& Coupland G. (2008). Phloem transport of flowering signals. Current Opinion in Plant Biology, 11, 687-694. http://dx.doi.org/10.1016/j.pbi.2008.10.003

Gundersen D.E. \& Lee I.-M. (1996). Ultrasensitive detection of phytoplasmas by nested-PCR assays using two universal pairs. Phytopthologia Mediterranea, 35, 144-151.

Hodgettes J. \& Dickinson M. (2010). Phytoplasma phylogeny and detection based on genes other than 16S rRNA. In: Phytoplsmas genomes, plant hosts and vectors (Eds P.G. Weintraub \& P. Jones) pp. 93-114. CABI.

Hogenhout S.A., Oshima K., Ammar E.-D., Kakizawa S., Kingdom H.N. \& Namba S. (2008). Phytoplasmas: bacteria that manipulate plants and insects. Molecular Plant Pathology, 9, 403-423. http://dx.doi.org/10.1111/j.1364-3703.2008.00472.x

Horváth J. (1969). Green petal: A new disease of rape in Hungary. Acta Phytopathologica Academiae Scientiarum Hungaricae, 4, 363-367.

Kamińska M., \& Dziekanowska D. (2001). Detection of aster yellows phytoplasma in Tagetes patula plants with two types of symptoms. Phytopathologica Polonica, 21, 81-92.

Kamińska M. \& Soika G. (2002). The occurrence of aster yellows phytoplasma symptoms and leafhoppers (Auchenorrhyncha) on annual ornamental crops. Phytopathologica Polonica, 22, 71-82. 
Kamiński P., Berniak H. \& Kamińska M. (2010). 'Candidatus Phytoplasma Asteris' identified in Brussels sprouts and its possible association with flower bud failure in Poland. $17^{\text {th }}$ Crucifer Genetics Workshop BRASSICA 2010, 5-8.09.2010, Saskatoon, Canada. Book of abstracts, 97.

Kison H. \& Seemüller E. (2001). Differences in strain virulence of the European stone fruit yellows phytoplasma and susceptibility of stone fruit trees on various rootstocks to this pathogen. Journal of Phytopathology, 149, 533-541. http://dx.doi.org/10.1046/j.1439-0434.2001.00671.x

Lee I.M., Dane R. A., Black M.C. \& Troxclair N. (2001). First report of an aster yellows phytoplasma associated with cabbage in southern Texas. Plant Disease, 85, 447. http://dx.doi.org/10.1094/PDIS.2001.85.4.447B

Lee I.M., Davis R.E., \& Gundersen-Rindal D.E. (2000). Phytoplasmas: phytopathogenic mollicutes. Annual Review of Microbiology, 54, 221-255. http://dx.doi.org/10.1146/annurev.micro.54.1.221

Lee I.M., Hammond R.W., Davis R.E. \& Gundersen D.E. (1993). Universal amplification and analysis of pathogen 16S rDNA for classification and identification of mycoplasmalike organisms. Phytopathology, 8, 834-842. http://dx.doi.org/10.1094/Phyto-83-834

Lee I.-M., Martini M., Bottner K. D., Dane R. A., Black M. C. \& Troxclair N. (2003). Ecological implications from a molecular analysis of phytoplasmas involved in an aster yellows epidemic in various crops in Texas. Phytopathology, 93, 1368-1377. http://dx.doi.org/10.1094/PHYTO.2003.93.11.1368

Lee I.M., Gundersen-Rindal D. E., Davis R. E., Bottner K. D., Marcone C. \& Seemüller E. (2004). 'Candidatus Phytoplasma asteris', a novel phytoplasma taxon associated with aster yellows and related diseases. International Journal of Systematic and Evolutionary, 54, 1037-1048. http://dx.doi.org/10.1099/ijs.0.02843-0

Lepka P., Stitt M., Moll E. \& Seemüller E. (1999). Effect of phytoplasmal infection on concentration and translocation of carbohydrates and amino acids in periwinkle and tobacco. Physiology and Molecular Plant Pathology, 55, 59-68. http://dx.doi.org/10.1006/pmpp.1999.0202

Maliogka V.I., Tsialtas J.T., Papantoniou A., Efthimiou K. \& Katis N.I. (2009). First report of a phytoplasma associated with an oilseed rape disease in Greece. New Disease Reports, 18, 53. [Online] Available: http://www.bspp.org.uk/ndr

Marcone C.F., Lee I.-M., Davis R.E., Ragozzino A. \& Seemüller, E. (2000). Classification of aster yellows group phytoplasma based on combined analyses of rRNA and tuf gene sequences. International Journal of Systematic and Evolutionary, 50, 1703-1713.

Marcone C., Ragozzino A. \& Seemüller E. (1997). Detection and identification of phytoplasmas infecting vegetable, ornamental, and forage crops in southern Italy. Journal of Plant Pathology, 79, 211-217.

Marcone C. \& Ragozzino A. (1995). Detection of phytoplasmas in Brassica spp. in southern Italy and their characterization by RFLP analysis. Zeitschrift für Pflanzenkrankheiten und Pflanzenschutz, 102, 449-460.

Marzachì C., Alma A., Aquilio M.d', Minuto G. \& Boccardo G. (1999). Detection and identification of phytoplasmas infecting cultivated and wild plants in Liguria (Italian Riviera). Journal of Plant Pathology, 81, 127-136.

Musetti R. (2010). Biochemical changes in plants infected by phytoplasmas. In: Phytoplsmas genomes, plant hosts and vectors (Eds P.G. Weintraub \& P. Jones), pp. 132-146. CABI.

Olivier C.Y., Séguin-Swartz G., Barasubiye T. \& Hegedus D. (2006). First report of 'Candidatus Phytoplasma asteris'-related strains in Brassica rapa in Saskatchewan, Canada. Plant Disease, 90, 832. http://dx.doi.org/10.1094/PD-90-0832C

Salehi M., Izadpanah K. \& Siampour M. (2007). Characterization of a phytoplasma associated with cabbage yellows in Iran. Plant Disease, 91, 625-630. http://dx.doi.org/10.1094/PDIS-91-5-0625

Schneider B., Seemüller E., Smart C.D. \& Kirkpatrick B.C. (1995). Phylogenetic classification of plant pathogenic mycoplasma-like organisms or phytoplasmas. In: Molecular and Diagnostic Procedures in Mycoplasmology (Eds S. Razin \& J.G Tully), pp. 369-380. Academic Press, San Diego, CA, USA. http://dx.doi.org/10.1016/B978-012583805-4/50040-6

Seemüller E., Marcone C., Lauer U., Ragozzino A. \& Göschl M. (1998). Current status of molecular classification of the phytoplasmas. Journal of Plant Pathology, 80, 3-26.

Shaw M.E., Kirkpatrick B.C. \& Golino D.A. (1993). The beet leafhopper-transmitted virescence agent causes tomato big bud disease in California. Plant Disease, 77, 290-295. http://dx.doi.org/10.1094/PD-77-0290 
Soika G. \& Kamińska M. (2001). Effectiveness of some insecticides in the control of Macrosteles laevis (Rib.) and protection of annual ornamental plants against aster yellows (AY) phytoplasma. Journal of Fruit and Ornamental Plant Research, 8, 155-167.

Starzycki M. \& Starzycka E. (2000). Parents and progeny plant deformation of Brassica napus L. infected by Phytoplasma sp. Rośliny Oleiste - Oilseed Crops, 21, 399-408.

Śliwa H., Kamińska M., Korszun S. \& Adler P. (2008). Detection of 'Candidatus Phytoplasma pini' in Pinus sylvestris trees in Poland. Journal of Phytoplathology, 156, 88-92. http://dx.doi.org/10.1111/j.1439-0434.2007.01335.x

Tamura K., Dudley J., Nei M. \& Kumar S. (2007). MEGA4: molecular evolutionary genetics analysis (MEGA) software version 4.0. Molecular Biology and Evolution, 24, 1596-1599. http://dx.doi.org/10.1093/molbev/msm092

Vibio M., Bertaccini A., Lee I.-M., Davis R. E. \& Clark M.F. (1996). Differentiation and classification of aster yellows and related European phytoplasmas. Phytopathologia Mediterranea, 35, 33-42.

Wang K. \& Hiruki C. (2001). Molecular characterization and classification of phytoplasmas associated with canola yellows and a new phytoplasma strain associated with dandelions. Plant Disease, 85, 546-552. http://dx.doi.org/10.1094/PDIS.2001.85.1.76

Weintraub P.G. \& Beanland L. (2006). Insect vectors of phytoplasmas. Annual Review of Entomology, 51, 91-111. http://dx.doi.org/10.1146/annurev.ento.51.110104.151039

Winfield M.O., Lu C., Wilson I.D., Coghill J.A. \& Edwards K.J. (2009). Cold- and light-induced changes in the transcriptome of wheat leading to phase transition from vegetative to reproductive growth. BMC Plant Biology, 9 , 55. http://dx.doi.org/10.1186/1471-2229-9-55

Zhao Y., Wei W., Davis R.E. \& Lee I.M. (2010). Recent advances in 16S rRNA gene-based phytoplasma differentiation, classification and taxonomy. In: Phytoplasmas genomes, plant hosts and vectors (Eds P.G. Weintraub \& P. Jones), pp. 64-92. CABI.

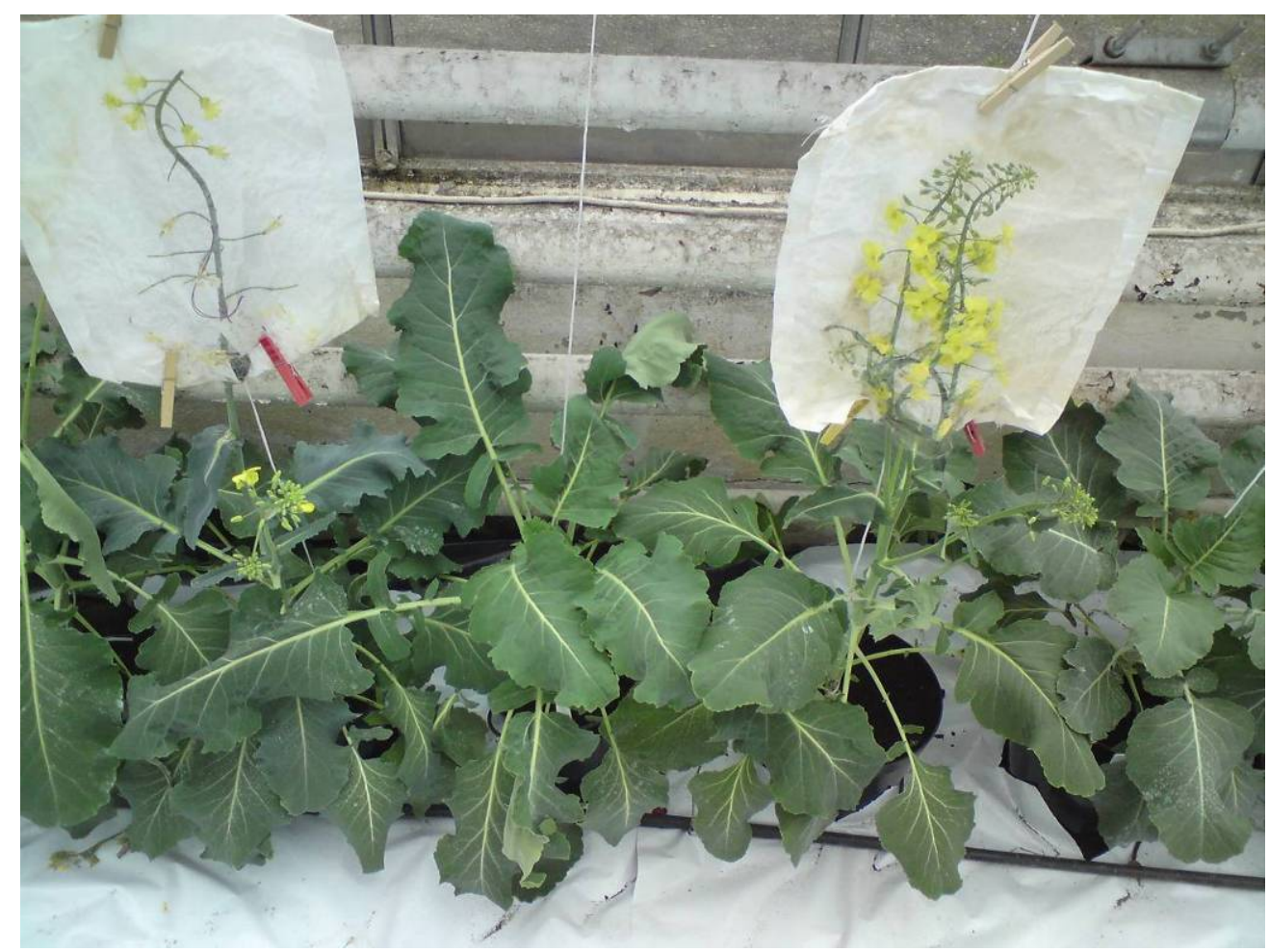

Figure 1. Interspecific crosses of Brassica oleracea X Brassica napus plants with failure of flower buds and two healthy plants with flowers 


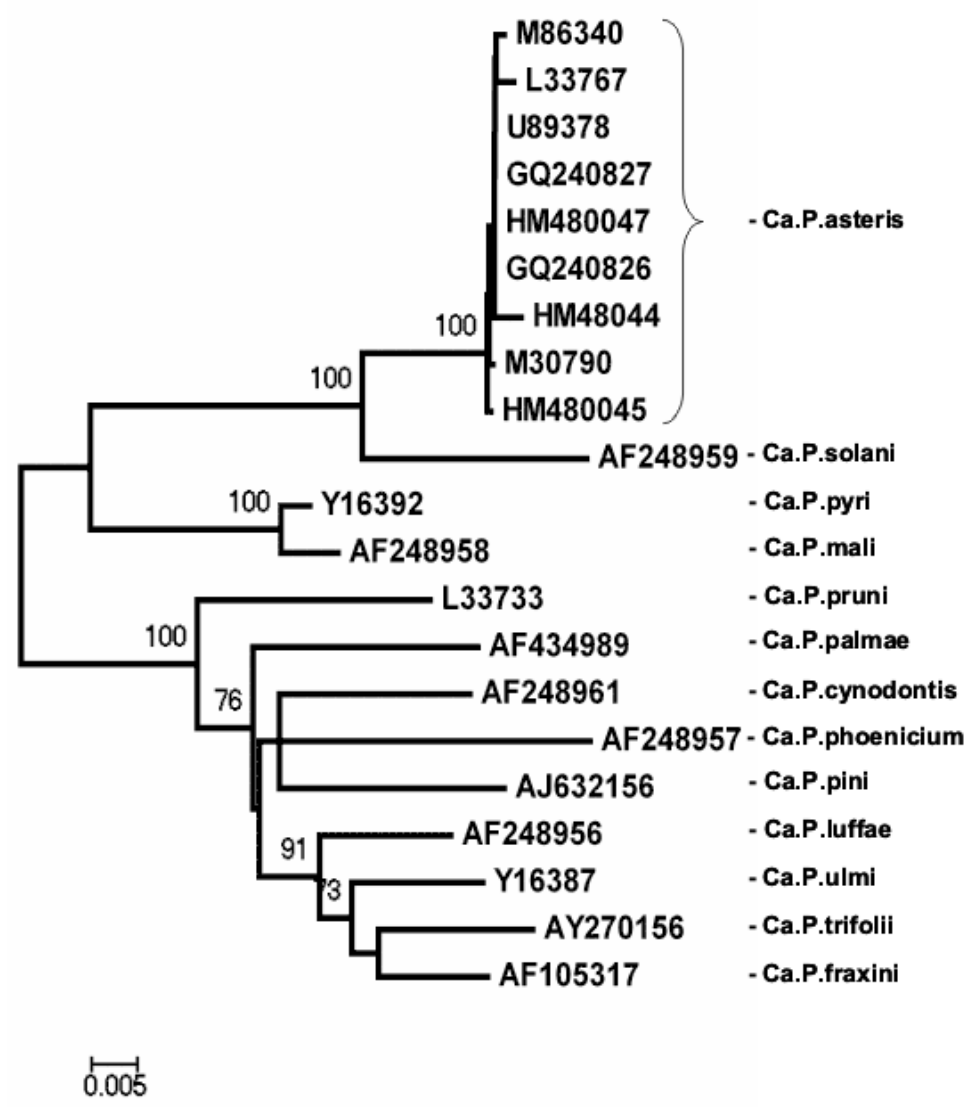

Figure 2. Phylogenetic tree based on 16S rRNA gene sequences of phytoplasma isolates from interspecific crosses of Brassica oleracea x B. napus (HM480044 and HM480045) and sequences of selected phytoplasma strains belonging to $12 \mathrm{Ca}$. phytoplasma groups. The bar represents 0.005 nucleotide substitutions per position 